\title{
Bio Diesel from Castor Oil - A Green Energy Option
}

\author{
Hemant Y. Shrirame ${ }^{1}$, N. L. Panwar ${ }^{2}$, B. R. Bamniya ${ }^{3}$ \\ ${ }^{1}$ College of Agricultural Engineering and Technology, Dr. B. S. Konkan Krishi Vidyapeeth, Maharashtra, India; ${ }^{2}$ Department of Re- \\ newable Energy Sources, College of Technology and Engineering Maharana Pratap University of Agriculture and Technology, Ra- \\ jasthan, India; ${ }^{3}$ Department of Environmental Sciences, Mohan Lal Sukhadia University, Udaipur, Rajasthan, India. \\ Email: nlpanwar@rediffmail.com
}

Received February $5^{\text {th }}, 2011$; revised February 12 $2^{\text {th }}, 2011$; accepted February $26^{\text {th }}, 2011$.

\begin{abstract}
With increase in the demand of petroleum products the prices of petrol \& diesel are increasing world wide. This trend is expected in years to come as the resources are also depleting. Hence alternative sources of energy for running our generators, automobiles etc. are being considered world wide. The possibility of obtaining oil from plant resources has aroused a great interest and in several countries, vegetable oil after esterification being used as "Biodiesel". The biodiesel can be used as $20 \%$ blend with petrodiesel in existing engines without any modification. Both the edible and non edible vegetable oils can be used as the raw materials for the biodiesel. Considering the cost and demand of the edible oils the non edible oils may be preferred for the preparation of biodiesel in India.
\end{abstract}

Keywords: Biodiesel, Castor Seed Oil, Emissions, Green Energy, Non Edible Oil

\section{Introduction}

Energy is the basic need for economic development of any country. The single largest source of energy in India after coal is petroleum, about two third of which is imported from OPEC (Oil and Petroleum Exporting Countries). In India energy consumption is increasing at rapid rate due to rapid industrialization, transportation and mechanization. At present, India is the sixth biggest country in the world and second highest country after china in Asia in terms of energy demand. High dependency on imported fuel and due to rapid rise in petroleum prices may make Indian economy insecure from energy demand.

As per Planning Commission (Government of India) estimates, the requirement of petrol is expected to grow from approximately 7 million tons in 2001 to 10 million tons in 2006 and 12.5 million tons in 2012. Similarly, the demand for diesel is likely to touch the level of about 52 million tons in 2006 and 66 million tons in 2012.

Coal is the most important \& abundant fossil fuel in India and accounts for 55\% of India's energy need. India's industrial heritage was built upon indigenous coal, largely mined in the eastern and the central regions of the country. Thirty per cent of commercial energy requirements are met by petroleum products, nearly 7.5 percent by natural gas and 3.5 percent by primary electricity.

India is, however, poorly endowed with oil assets and has to depend on crude imports to meet a major share of its needs (around 70 percent). A large population of India in the rural areas depends on traditional sources of energy such as firewood, animal dung and biomass. The usage of such sources of energy is estimated at around approximately 47 percent of total primary energy use.

\section{Biodiesel}

Biodiesel is the product one gets when organically derived oil such as vegetable oil or animal fat chemically reacts with an alcohol to produce a fatty acid alkyl ester [1]. It has become an interesting alternative to be used in diesel engine, because it has similar properties to the traditional fossil diesel fuel and may, thus, substitute conventional fuel with none or very minor engine modification [2]. One of the attractive features of biodiesel is its biodegradability and being more environmental friendly than the fossil fuels, resulting in less environmental impact upon accidental release to the environment [3]. Emissions such as total hydro carbons and $\mathrm{CO}$ are usually found to significantly low with biodiesel as compared to petroleum diesel. This may be due to more complete combustion caused by the increased oxygen content in the flame coming from the biodiesel molecules. It is al- 
ways recommended to produce biodiesel use waste edibles oil or non-edibles oil such as jatropha, caster, pongamia pinnata, rubber seed and mango. Table 1 shows oil yield of major non-edible and edible oil [4].

Jaecker-Voirol et al., [6] reported an emission performance test for various biodiesel formulations including di- and tri-glyceryl ethersbiodiesel blends releasing less regulated and toxic air pollutants compared with biodiesel alone. However, the use of isobutene to produce di- and tri-glyceryl ethers from glycerol needs further research as isobutene is expensive, currently made from non-renewable source and requires high pressure for the glycerol etherification reaction. A study was reported in Indian context that if $10 \%$ of total production of castor seed oil is transesterfied into biodiesel, then about 79,782 tons of $\mathrm{CO}_{2}$ emission can be saved on annual basis. The $\mathrm{CO}_{2}$ released during combustion of biodiesel can be recycled through next crop production, therefore, no additional burden on environment [7].

\section{Energy Security}

Increasing pressure of population and increasing use of energy in agriculture, industrial and the domestic and public sectors is an area of concern. At the same time, the need to meet energy demand has created huge capital requirements needed for setting up power plants, pipelines, ports, terminals, railway tracks to move fuel etc.

As India continues to grow at the rate of 8-9.5 percent, energy security has become a core issue. To alleviate concerns over energy security, the Government of India has taken multiple steps in recent years which include encouraging private sector participation, a more holistic approach towards broad basing its supply base, and improving efficiency in the sector as a whole [8].

High Speed Diesel (HSD) is the main transport fuel in

Table 1. Oil yield for major non-edible and edible oil sources.

\begin{tabular}{lll}
\hline Type of oil & Oil yield (kg oil/ha) & Oil yield (wt\%) \\
\hline Non-edible oil & & Seed: $35-40$ \\
Jatropha & 1590 & $40-50$ \\
Rubber seed & $80-120$ & 53 \\
Castor & 1180 & $30-40$ \\
Pongamia pinnata & $225-2250$ & N/A \\
Sea mango & N/A & \\
Edible oil & & 20 \\
Soybean & 375 & 20 \\
Palm & 5000 & $37-50$ \\
Rapeseed & 1000 &
\end{tabular}

India, hence introduction of biodiesel both as a diesel substitute and for blending with diesel is an imperative need. Mainly, biodiesel is being produced by the crops like sunflower, soybean, mustard oil etc in many parts of the world. As the nation is facing a shortage of edible oils, it would not be feasible to produce biodiesel by edible oils. However, the country has enormous potential to produce tree borne oilseeds for biodiesel production to cope with the demand of about 40 percent diesel requirement from total crude oil.

Biodiesel is nothing but fatty acid methyl or ethyl esters made from edible and non-edible oils and animal fats. The main commodity sources for biodiesel in India can be non-edible oils obtained from plant species such as Ratanjot (Jatropha curcus), Karanja (Pongamia pinnata), Castor (Ricinus communis) oilseed etc. It contains no petroleum, but it can be blended at any level with petroleum diesel to create a biodiesel blend or can be used in its pure form $[9,10]$

\section{Castor Oil}

A colorless or pale yellowish oil extracted from the seeds of the castor-oil plant, Castor (Ricinus communis $L$ ) is cultivated around the world because of the commercial importance of its oil which is used in the manufacture of a number of industrial chemicals like surfactants, greases and lubricants, specialty soaps, surface coatings, cosmetics and personal care products, pharmaceuticals, etc.

The Indian variety of castor seed has an oil content of $48 \%$ and $42 \%$ can be extracted. The residual oil cake, which contains about 5.5 percent Nitrogen, 1.8-1.9 percent Phosphorus and 1.1 percent Potassium, is used as organic manure. Castor grows well under hot and humid tropical conditions and has a growing period of 4 to 5 months. It can be grown either as a pure crop in rotation with wheat, linseed etc., or is grown mixed with cotton, groundnut, arhar, green gram, jowar, bajra and cowpea. The average yield of seed per hectare and oil per hectare is $1250 \mathrm{~kg} /$ hectare and 550 lit/hectare India is the world's largest producer and exporter of castor oil [11]. It is currently cultivated on about 700,000 hectares mostly in Gujarat and Andhra Pradesh under rain fed conditions. The yield in terms of oil varies from $350-650 \mathrm{~kg}$ of oil per hectare when no maintenance is applied to the crop i.e. fertilizers etc. [12].

The comparative advantage of Castor is that its growing period is much shorter than that of Jatropha and Pongamia, and there is considerably greater experience and awareness among farmers about its cultivation. Being an annual crop it gives the farmers the ability to rotate or shift away easily depending on market conditions.

However, among vegetable oils, castor oil is distin- 
guished by its high content (over $85 \%$ ) of ricinoleic acid. No other vegetable oil contains so high a proportion of fatty hydroxyacids. Castor oils unsaturated bond, high molecular weight (298), low melting point $\left(5^{\circ} \mathrm{C}\right)$ and very low solidification point $\left(-12^{\circ} \mathrm{C}\right.$ to $\left.-18^{\circ} \mathrm{C}\right)$ make it industrially useful, most of all for the highest and most stable viscosity of any vegetable oil. The physical properties of the vegetable oils are shown in Table 2. The physical and chemical properties of the methyl esters produced are shown in Table 3. The values are compared with ASTM standard for bio diesel.

\section{The Chemical Composition of Castor Oil is [12]}

- $\quad$ Ricinoleic Acid - 89.5\%
- Linoleic Acid - $4.2 \%$

- Oleic Acid - 3\%

- Stearic Acic - 1\%

- Palmitic Acid - 1\%

- Dihydroxystearic Acid - 0.7\%

- Linolenic Acid - 0.3\%

- Eicosanoic Acid - 0.3\%)

\subsection{Cost of Castor Oil}

The following were the spot prices for the various oils in India on March 10, 2006 in Indian rupees/Kg (One US \$ equals 45 Indian rupees, approximately).

- Castor Oil - 32.3

- Groundnut Oil/Peanut Oil - 43.6

- Mustard Oil - 36.4

Table 2. Physical properties of the vegetable oils.

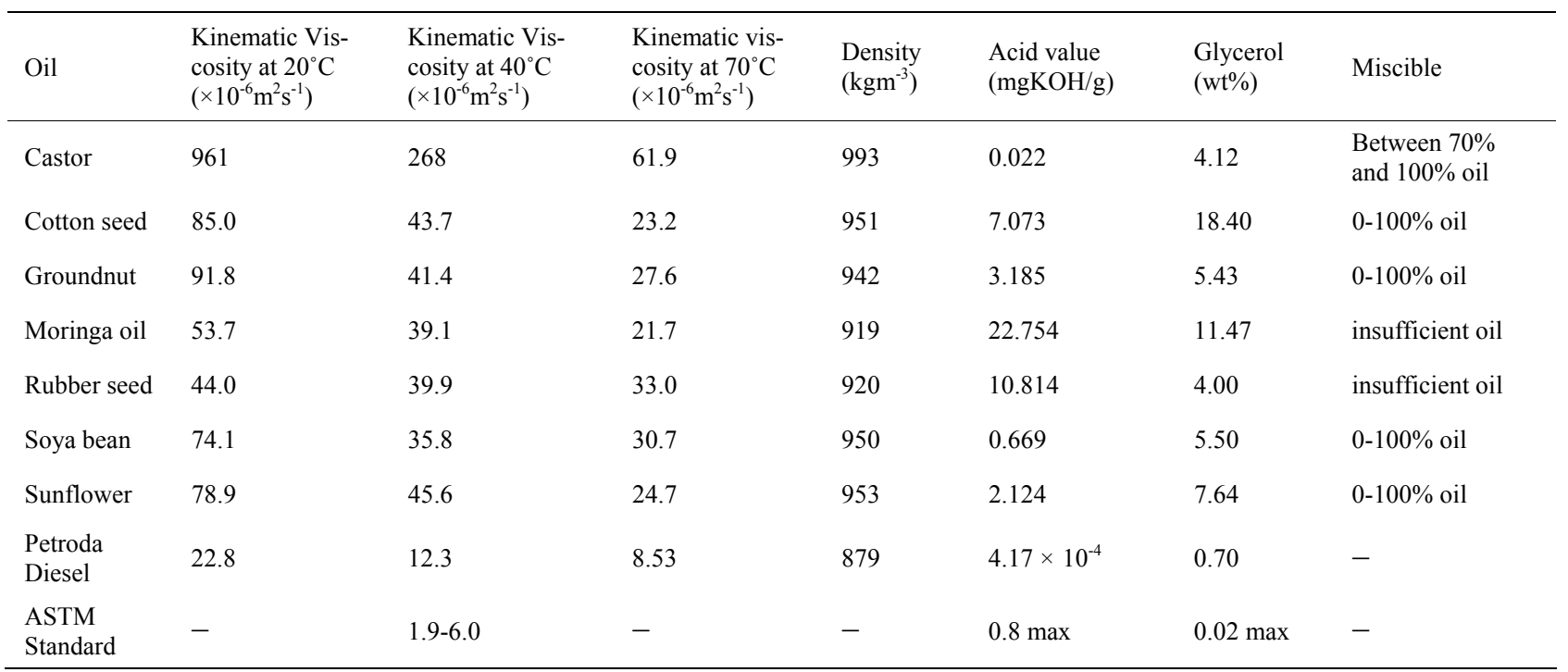

(Sources: http://www.chanco.unima.mw/physics/biodieselanaly.html)

Table 3. Physical and chemical properties of the methyl esters.

\begin{tabular}{|c|c|c|c|c|c|c|}
\hline Methyl Ester & $\begin{array}{l}\text { Kinematic } \\
\text { Viscosity at } 20^{\circ} \mathrm{C} \\
\left(\times 10^{-6} \mathrm{~m}^{2} \mathrm{~s}^{-1}\right)\end{array}$ & $\begin{array}{l}\text { Kinematic } \\
\text { Viscosity at } 40^{\circ} \mathrm{C} \\
\left(\times 10^{-6} \mathrm{~m}^{2} \mathrm{~s}^{-1}\right)\end{array}$ & $\begin{array}{l}\text { Kinematic } \\
\text { Viscosity at } 70^{\circ} \mathrm{C} \\
\left(\times 10^{-6} \mathrm{~m}^{2} \mathrm{~s}^{-1}\right)\end{array}$ & $\begin{array}{l}\text { Density } \\
\left(\mathrm{kgm}^{-3}\right)\end{array}$ & $\begin{array}{l}\text { Acid Value } \\
(\mathrm{mgKOH} / \mathrm{g})\end{array}$ & Glycerol (wt $\%)$ \\
\hline Castor & 40.6 & 19.4 & 15.8 & 956 & $6.24 \times 10^{-3}$ & 80.39 \\
\hline Cotton seed & 25.0 & 23.1 & 16.1 & 921 & $2.04 \times 10^{-3}$ & 3.44 \\
\hline Groungnut & 22.0 & 15.4 & 7.16 & 908 & $7.20 \times 10^{-4}$ & 1.03 \\
\hline Moringa & 22.4 & 13.3 & 11.1 & 903 & $2.13 \times 10^{-3}$ & 0.81 \\
\hline Rubber seed & 23.9 & 21.7 & 19.8 & 891 & $6.29 \times 10^{-3}$ & 21.91 \\
\hline Soya bean & 18.8 & 11.1 & 6.56 & 915 & $1.56 \times 10^{-3}$ & 8.69 \\
\hline Sunflower & 18.9 & 13.2 & 8.80 & 909 & $3.07 \times 10^{-3}$ & 4.46 \\
\hline petroda Diesel & 22.8 & 12.3 & 8.53 & 879 & $6.24 \times 10^{-3}$ & 0.7 \\
\hline ASTM standard & - & $1.9-6.0$ & - & - & $0.8 \max$ & $0.02 \max$ \\
\hline
\end{tabular}

(Sources: http://www.chanco.unima.mw/physics/biodieselanaly.html) 
- Palm Oil (RBD) - 38.1, Palm Oil Crude - 36.4

- Refined Soy Oil - 36.7

\subsection{Typical Extractions of Oil from Oilseeds}

(Kg of oil from $100 \mathrm{~kg}$ of oilseed)

\section{Oilseed Extraction}

$\begin{array}{ll}\text { Castor } & 36 \\ \text { Palm } & 36 \\ \text { Rapeseed } & 37 \\ \text { Soybean } & 14 \\ \text { Sunflower } & 32\end{array}$

\subsection{Yield Comparison of Castor Oil with Other Plant Oil Biodiesel Candidates}

$\begin{array}{ll}\text { Crop Oil in Liters per hectare } \\ \text { Castor } & 1413 \\ \text { Sunflower } & 952 \\ \text { Safflower } & 779 \\ \text { Palm } & 5950 \\ \text { Soy } & 446 \\ \text { Coconut } & 2689\end{array}$

\section{World Scenario}

India is the leading producer of castor oil in the world, followed by China and Brazil with 0.8 and 0.4 lakh tons respectively. The present annual world trade in castor oil is estimated at about 2.0-2.50 lakh tons. The major importers of castor oil in the world market are European Union, US and Japan. The world demand for castor oil is estimated to be growing at the rate of about 3 to $5 \%$ per annum. Both Brazil and China have experienced a steady increase in their domestic castor oil consumption in the recent years and thus utilize almost their entire production. India consumes only a quarter of its castor oil production and exports the rest [13].

\subsection{Indian Scenario}

- India is the world leader in castor seed and oil production and dominates the international castor oil trade.

- The Indian variety of castor has $48 \%$ oil content of which $42 \%$ can be extracted, while the cake retains the rest.

- India's castor oil production fluctuates between 2.5-3.5 lakh tons a year. In 2003-04, India's estimated castor oil production was 2.8 lakh tons.

- Gujarat accounts for $86 \%$ of India's castor seed production followed by Andhra Pradesh and Rajasthan. Castor is mainly grown in Mehsana, Banaskantha and Saurashtra/Kutch regions of Gujarat and Nalgonda and Mahboobnagar districts of Andhra Pradesh.

- Castor is a Kharif crop. The sowing season of cas- tor is from July to October and the harvesting season is from October to April.

- The annual domestic consumption of castor oil in India is only about $80000-100000$ tons. Of this, the soap industry consumes about 25000 tons, the paint and allied industries 35000 tons and the lubricant and derivatives industry 20,000 tons.

- India annually exports around 2.0-2.4 lakh tons of commercial castor oil. From India castor oil is exported in two forms - First Special Grade and Castor Oil Commercial through mainly Kandla port. There is a large scope for improving India's earning from castor by converting the castor oil to various derivatives.

- A considerable quantity of the castor oil is also used in adulteration of edible oils like groundnut oil due to price differential.

\subsection{Castor Oil in Food}

In the food industry, Castor oil (food grade) is used in food additives, flavorings, candy (i.e., chocolate), as a mold inhibitor, and in packaging. Polyoxyethylated Castor oil is also used in the foodstuff industries [14].

\subsection{Medicinal Use of Castor Oil}

Today, the United States Food and Drug Administration (FDA) recognizes Castor oil as generally safe and effecttive (GRASE) for over-the-counter use as a laxative, but it is not a preferred drug to treat constipation. Besides being a laxative, Castor oil is sometimes used to help women start labor, but in any case with due caution and under medical supervision. One of Castor oil's derivatives undecylenic acid is also FDA approved for overthe-counter use on skin disorders or skin problems.

\section{Energy Content of Biofuels}

The specific energy densities $(\mathrm{MJ} / \mathrm{kg})$ of various fuels

\subsection{Solid Fuels}

Wood Fuel - 16-21

\subsection{Liquid Fuels}

$$
\begin{array}{cl}
\text { Methanol - 20-23 } \\
\text { - } & \text { Ethanol - 24-27 } \\
\text { - } & \text { Butanol - 36 } \\
\text { - } & \text { Biodiesel - } 38
\end{array}
$$

\subsection{Gaseous Fuels}

Methane - 55-56

- Hydrogen - 120-140

\subsection{Fossil Fuels (for Comparison)}

- Coal-29-34 


\section{Advantages of Biodiesel}

Advantages \& Benefits,

- Biodiesels are biodegradable, non-toxic, less greenhouse gases emissions than petroleum-based diesel, renewable source of energy.

- Biodiesel is the only alternative fuel that runs in any conventional, unmodified diesel engine.

- Biodiesel can be used alone or mixed in any ratio with petroleum diesel fuel. The most common blend however is a mix of $20 \%$ biodiesel with $80 \%$ petroleum diesel, or "B20".

- Biodiesel is about $10 \%$ oxygen by weight and contains no sulfur. The lifecycle production and use of biodiesel produces approximately $80 \%$ less carbon dioxide emissions, and almost $100 \%$ less sulfur dioxide.

- Combustion of biodiesel alone provides over $90 \%$ reduction in total unburned hydrocarbons, and a $75-90 \%$ reduction in aromatic hydrocarbons.

- Biodiesel has a very high flash point (300 F) making it one of the safest of all alternative fuels, from a combustibility point.

\section{Bio-Diesel Produced from Castor Oil}

The major problem associated with the use of pure vegetable oils as fuels for diesel engines is caused by high fuel viscosity in compression ignition. The vegetable oils are all highly viscous, with viscosities ranging 10-20 times those of No. 2 Diesel fuel. Amongst vegetable oils in the context of viscosity, castor oil is in a class by itself, with a viscosity more than 100 times that of No. 2 Diesel fuel (MSDS of No. 2 Diesel Fuel - PetroCard). Due to their high viscosity and low volatility, they do not burn completely and form deposits in the fuel injector of diesel engines. Furthermore, acrolein (a highly toxic substance) is formed through thermal decomposition of glycerol.

Dilution, micro-emulsification, pyrolysis and transesterification are the four techniques applied to solve the problems encountered with the high fuel viscosity. Amongst the four techniques, chemical conversion of the oil to its corresponding fatty ester is the most promising solution to the high viscosity problem. This process chemical conversion of the oil to its corresponding fatty ester, and thus biodiesel - is called transesterification [15].

\subsection{Transesterification Process}

The transesterification process will be adopted for the preparation of ethyl ester or methyl ester of Castor (Ricinus communis) oil. In the preparation of ethyl ester (biodiesel), five distinct stages will be involved,
1) Heating of oil.

2) Preparation of alkaline mixture.

3) Adding of alkaline alcohol to oil and stirring the mixture.

4) Settling of separation of glycerol.

5) Washing of ethyl ester with water.

The biodiesel can be obtained by transesterification of castor oil using either ethanol or methanol as the Transesterification agent. The extraction of biodiesel from castor oil, in the presence of the catalysts faster with methanol as the transesterification agent compared with ethanol. The maximum yield of esters depends on the reaction time and that is 1 hour with methanol or of 5 hours with ethanol. However, while similar yields of fatty acid esters may be obtained following ethanolysis or methanolysis, the reaction times required to attain them are very different, with methanolysis being much more rapid [16]. The transesterification of castor oil via ethanolysis or methanolysis can be improved through the development of more efficient catalytic systems and processes, to maintain kinetic control of the reaction, and by optimization of purification procedures.

\section{Conclusions}

The vegetable oil-based fuel production is very attractive for developing countries like India. Vegetable oils are a renewable and potential inexhaustible source of energy with an energetic content close to diesel fuel. In addition to being available locally, renewable and cheap, biodiesel can make a good substitute for diesel fuel. The biodiesel is found to burn more efficiently than diesel [17]. The emission of carbon monoxide, hydrocarbon, oxides of nitrogen and smoke were decreased by 58, 63, 12 and 70 percent, respectively, in comparison with diesel.

\section{REFERENCE}

[1] C. S. Jr. Wassell and T. P. Dittmer, "Are Subsidies for Biodiesel Economically Efficient?" Energy Policy, Vol. 34, No. 18, 2006, pp. 3993-4001.

[2] N. L. Panwar, Y. H. Shrirame, N. S. Rathore, S. Jindal and A. K. Kurchania, "Performance Evaluation of a Diesel Engine Fueled with Methyl Ester of Castor Seed Oil," Applied Thermal Engineering, Vol. 30, No. 2-3, pp. 245-249, 2010.

doi:10.1016/j.applthermaleng.2009.07.007

[3] J. Janaun and N. Ellis. "Perspectives On Biodiesel as a Sustainable Fuel," Renewable and Sustainable Energy Reviews, Vol. 14, No. 4, 2010, pp. 1312-1320. doi:10.1016/j.rser.2009.12.011

[4] M. Lapuerta, O. Armas and J. R. Fernandez. "Effect of Biodiesel Fuels on Diesel Engine Emissions," Progress in Energy and Combustion Science, Vol. 34, No. 2, 2008, pp. 198-223. doi:10.1016/j.pecs.2007.07.001 
[5] M. M. Gui, K. T. Lee and S. Bhatia, "Feasibility of Edible Oil VS. Non-Edible Oil VS. Waste Edible Oil as Biodiesel Feedstock," Energy, Vol. 33, No. 11, 2008, pp. 1646-1653. doi:10.1016/j.energy.2008.06.002

[6] A. Jaecker-Voirol, I. Durand, G. Hillion, B. Delfort and X. Montagne "Glycerin for New Biodiesel Formulation," Oil Gas Science Technology, Vol. 63, No. 4, 2008, pp. 395-404. doi:10.2516/ogst:2008033

[7] N. L. Panwar, H. Y. Shrirame and B. R. Bamniya. " $\mathrm{CO}_{2}$ Mitigation Potential from Biodiesel of Castor Seed Oil in Indian Context," Clean Technologies and Environmental Policy, Vol. 12, No. 5, 2010, pp. 579- 582. doi:10.1007/s10098-009-0269-5

[8] Website of Atomic Energy Commission, India.

[9] N. S. Rathore, N. L. Panwar and A. K. Kurchania, "Jatropha Cutlivation and Processing Practices," Himanshu Publication, Udaipur.

[10] http://www.globalinsight.com/Energy (Retrieved 10 March 2008).
[11] D. Rajagopal, "Rethinking Current Strategies for Biofuel Production in India," Energy and Resources Group, University of California, Berkeley, 2007.

[12] www.castoroil.in (Retrieved 10 March 2008).

[13] www.worldenergy.org (Retrieved 16 January 2008).

[14] http://www.Answers.com (Retrieved 16 January 2008).

[15] Biodiesel WWW Encyclopedia - Plant Oils Used as Diesel, Bio-fuels, Biodiesel_Biofuel, Bio-diesel.htm

[16] M. S. P. Meneghetti et al., "Biodiesel from Castor Oil: A Comparison of Ethanolysis versus Methanolysis," Energy \& Fuels, Vol. 20, No. 5, 2006, pp. 2262-2265. doi:10.1021/ef060118m

[17] S. Puhan et al., "Performance and Emission of Mahua Oil (Madhuca Indica Oil) Ethyl Ester in a 4-Stroke Natural Aspirated Direct Injection Diesel Engine," Renewable Energy, Vol. 30, No. 7, 2005, pp. 1269-1278. doi:10.1016/j.renene.2004.09.010 